\title{
THREE FOLIICOLOUS TAXA OF LEJEUNEACEAE (MARCHANTIOPHYTA) NEW TO INDIA FROM GREAT NICOBAR BIOSPHERE RESERVE, ANDAMAN AND NICOBAR ISLANDS
}

\author{
M. DeY $Y^{1}$ and D. K. SINGH ${ }^{2}$ \\ ${ }^{1}$ Botanical Survey of India, Central National Herbarium, Howrah-711 103, India \\ E-mail:drmdey2010@gmail.com \\ ${ }^{2}$ Botanical Survey of India, CGO Complex, 3rd MSO Building, Block F (5th floor) \\ Salt Lake Sector I, Kolkata-700 064, India; E-mail: singh_drdk@rediffmail.com
}

(Received 4 February, 2015; Accepted 5 September, 2015)

Three liverworts belonging to family Lejeuneaceae (Marchantiophyta), Cololejeunea equialbi, Colura pluridentata and Drepanolejeunea thwaitesiana var. thwaitesiana are being reported as new to Indian flora from Great Nicobar Biosphere Reserve in the Andaman and Nicobar Islands. The diversity and distribution of the genera Cololejeunea, Colura and Drepanolejeunea in India have been discussed.

Key words: Andaman and Nicobar Islands, Cololejeunea equialbi, Colura pluridentata, Drepanolejeunea thwaitesiana, India, Lejeuneaceae, new record

\section{INTRODUCTION}

Lejeuneaceae is the largest family of liverworts in the world with approximately 1,000 species belonging to 68 currently accepted genera (Gradstein 2013). In India, the family is represented by about 197 taxa belonging to 24 genera (Singh and Singh 2013).

Recent studies on the liverworts of the Andaman and Nicobar Islands revealed the occurrence of three more taxa of the family Lejeuneaceae, which were hitherto unknown in the Indian liverwort flora. These are Cololejeunea equialbi Tixier, Colura pluridentata Ast and Drepanolejeunea thwaitesiana (Mitt.) Steph. var. thwaitesiana. The same have been described and illustrated in the present communication. 


\title{
DESCRIPTION AND DISCUSSION
}

\author{
Cololejeunea equialbi Tixier \\ Ann. Fac. Sci. Univ. Phnom Penh 3: 178 (1970)
}

(Figs 1; 4: 1-5)

Plants light green when fresh, yellowish green in herbarium; shoot 5-14 $\mathrm{mm}$ long, 1.2-1.5 mm wide; branching Lejeunea-type, irregular, sparse. Stem suborbicular to oval in outline in transverse section, 50.0-62.5 $\times 65.0-75.0$ $\mu \mathrm{m}, 3$ cells across the diameter; cortical cells in 5 vertical rows, rectangular to polygonal, $12.5-25.0 \times 20.0-35.0 \mu \mathrm{m}$, thin walled; medullary cell one, polygonal, 15.0-20.0 × 25.0-32.5 $\mu \mathrm{m}$, thin walled; ventral merophytes of stem 1 cell wide. Rhizoids numerous, fasciculate on ventral surface of stem, hyaline. Leaves closely or loosely imbricate, widely to downwardly spreading; leaf lobe elliptical, $0.55-0.80 \mathrm{~mm}$ long, $0.35-0.52 \mathrm{~mm}$ wide, apex rounded or rounded obtuse, margin irregularly finely denticulate with Allorgella-type of denticulations, dorsal margin arched, ventral margin slightly arched to nearly straight; apical leaf cells subquadrate, rectangular or polygonal, 10.0-20.0 $\times 10.0-22.5 \mu \mathrm{m}$; median leaf cells hexagonal, 20.0-30.0 × 17.5-25.0 $\mu \mathrm{m}$; basal leaf cells polygonal, $27.5-50.0 \times 17.5-30.0 \mu \mathrm{m}$; walls thin with minute trigones, intermediate thickenings absent; surface smooth; oil bodies not seen; leaf lobule spreading downward, inflated, $1 / 6-1 / 5$ as long as the leaf lobe, ovate, $0.11-0.15 \mathrm{~mm}$ long, $0.08-0.12 \mathrm{~mm}$ wide, bidentate; first tooth unicellular, oblong to slightly curved; second tooth obsolete; hyaline papilla oval to elliptical, present at the proximal side of first tooth; keel slightly arched to nearly straight, smooth; stylus unicellular. Gemmae discoid, on the ventral surface of leaf lobe, 16-26-celled, 45.0-62.5 × 50.0-70.0 $\mu \mathrm{m}$, adhesive cells not seen. Androecial and gynoecial branches not seen.

Habitat: Epiphyllous, growing on Ficus L. and Garcinia nervosa Miq. leaves in moist and shady condition, in association with Caudalejeunea recurvistipula (Gottsche) Schiffn., Cololejeunea floccosa (Lehm. et Lindenb.) Schiffn., Colura ari (Steph.) Steph., Drepanolejeunea thwaitesiana var. thwaitesiana, Lejeunea anisophylla Mont., Radula protensa Lindenb. and Radula tjibodensis K. I. Goebel.

Distribution: India (Andaman and Nicobar Islands (Great Nicobar Island: present study)), China, Fiji, Indonesia, Japan, Papua New Guinea, Philippines, Taiwan, Vietnam (Ellis et al. 2013, Mizutani 1975, 1978, 1986, Pócs et al. 1994, 2011, Zhu and So 2001).

Specimens examined: India, Andaman and Nicobar Islands, Great Nicobar Biosphere Reserve, East-West Road, 12 km from Campbell Bay, ca $145 \mathrm{~m}, 06^{\circ} 59^{\prime} 54^{\prime \prime} \mathrm{N}, 9^{\circ} 52^{\prime} 54^{\prime \prime}$ E, C. Murugan (61505C) 6 April 2013 (CAL); Great Nicobar Biosphere Reserve, Campbell Bay, $07^{\circ} 0.219^{\prime}$ N, $93^{\circ} 52.794^{\prime}$ E, D. K. Singh (61644E), 7 February 2014 (CAL). 
Cololejeunea equialbi is characterised by widely to downwardly spreading leaves (Figs 1: 1-2; 4: 1); elliptical leaf lobes with rounded or rounded obtuse apices and irregularly finely denticulate margins with Allorgella-type of denticulations (Figs 1: 5-9; 4: 2-3); thin walled leaf cells with minute trigones, devoid of intermediate thickenings (Figs 1: 9-11; 4: 3); ovate, inflated, bidentate leaf lobule, $1 / 6-1 / 5$ as long as the leaf lobe, spreading downward, with unicellular, oblong to slightly curved first tooth and obsolete second tooth (Figs 1: 2, 5-8, 12-13; 4: 1-2, 4); unicellular stylus (Figs 1: 14; 4: 5); and 16-26-celled discoid gemmae devoid of adhesive cells (Fig. 1: 15).

The Indian plants of $C$. equialbi are smaller in size as compared to the type from Vietnam, which are 1-2 cm long, $2.3 \mathrm{~mm}$ wide with larger leaves (1.2 $\mathrm{mm}$ long, $0.8 \mathrm{~mm}$ wide), but smaller (1/10 as long as the leaf lobe) leaf lobule (Tixier 1970). Our plants, however, compare well with their Chinese counterparts, which are 6-15 $\mathrm{mm}$ long and 1.0-1.9 $\mathrm{mm}$ wide with $0.7-1.1 \mathrm{~mm}$ long and $0.58-0.78 \mathrm{~mm}$ wide leaves, with the leaf lobule $1 / 6-1 / 5$ as long as the leaf lobe (Zhu and So 2001). The deviations shown by the Indian plants, therefore, are well within the range of variation recorded in the species across its range of distribution.

The genus Cololejeunea (Spruce) Schiffn. is represented in India by 51 species (Asthana and Alam 2013, Manju et al. 2012, Singh and Singh 2013). Among the Indian species of the genus, C. equialbi only partially resembles $C$. trichomanis (Gottsche) Steph. and C. tixieriana M. Dey, D. Singh et D. K. Singh in general appearance, the presence of rounded to obtuse leaf apices, smooth leaf surface, thin walled leaf cells with minute trigones and lack of intermediate thickenings. However, both species differ from C. equialbi in lacking downwardly spreading, elliptical leaf lobes with Allorgella-type of denticulations along the margins. They further differ in the presence of larger leaf lobule $(1 / 3$ as long as the leaf lobe) with 2(-3) cells long first tooth with hyaline papilla present at the inner surface of the base of first tooth; 2-3 (in C. tixieriana) or 4-6 (in C. trichomanis) cells long filiform stylus and gemmae with three adhesive cells (see also Asthana and Srivastava 2003, Dey and Singh 2012, Dey et al. 2008, Mizutani 1978, Zhu and So 2001).

With the present addition, the number of species of Cololejeunea in India has gone up to fifty-two (Table 1). The Eastern Himalaya, including the northeastern states show maximum diversity with 42 species of which 18 are restricted to this bryogeographical region alone in India, followed by the Western Ghats with 29 species of which nine are confined only to this region and the Andaman and Nicobar Islands with 10 species with two species known in the Indian bryoflora from this region only (Asthana and Alam 2013, Asthana and Sahu 2011, Asthana and Shukla 2010a, Asthana and Srivastava 2003, Daniels 2010, Daniels and Daniel 2009, Das and Singh 2009, Dey and Singh 2012, 

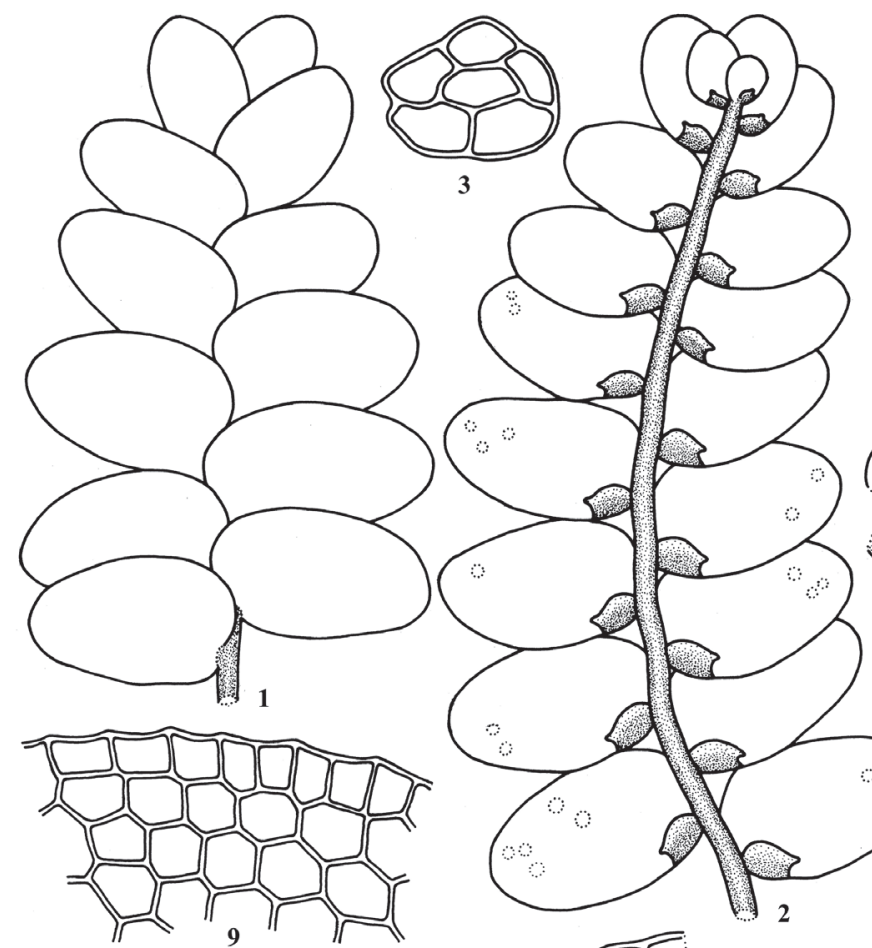

3
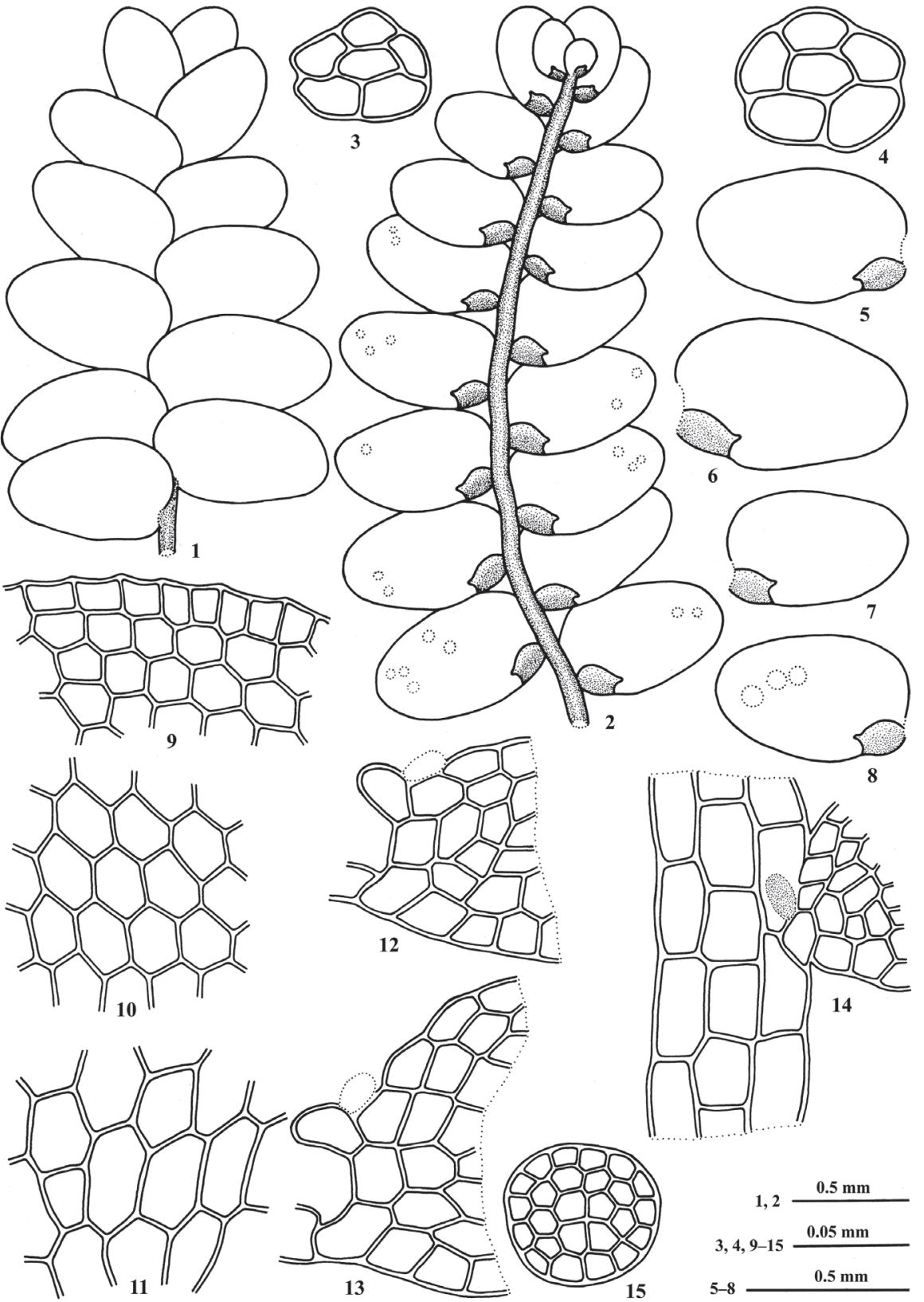

Fig. 1. Cololejeunea equialbi Tixier. $1=$ A portion of plant in dorsal view. $2=$ The same in ventral view (rhizoids not drawn). 3-4 = Transverse sections of stem. 5-8= Leaves. $9=$ Apical leaf cells. $10=$ Median leaf cells. $11=$ Basal leaf cells. $12-13=$ Apices of leaf lobules. $14=$ Base of leaf lobule and portion of stem showing a stylus. 15 = A gemma. (All drawn by M. Dey from C. Murugan 61505C) 


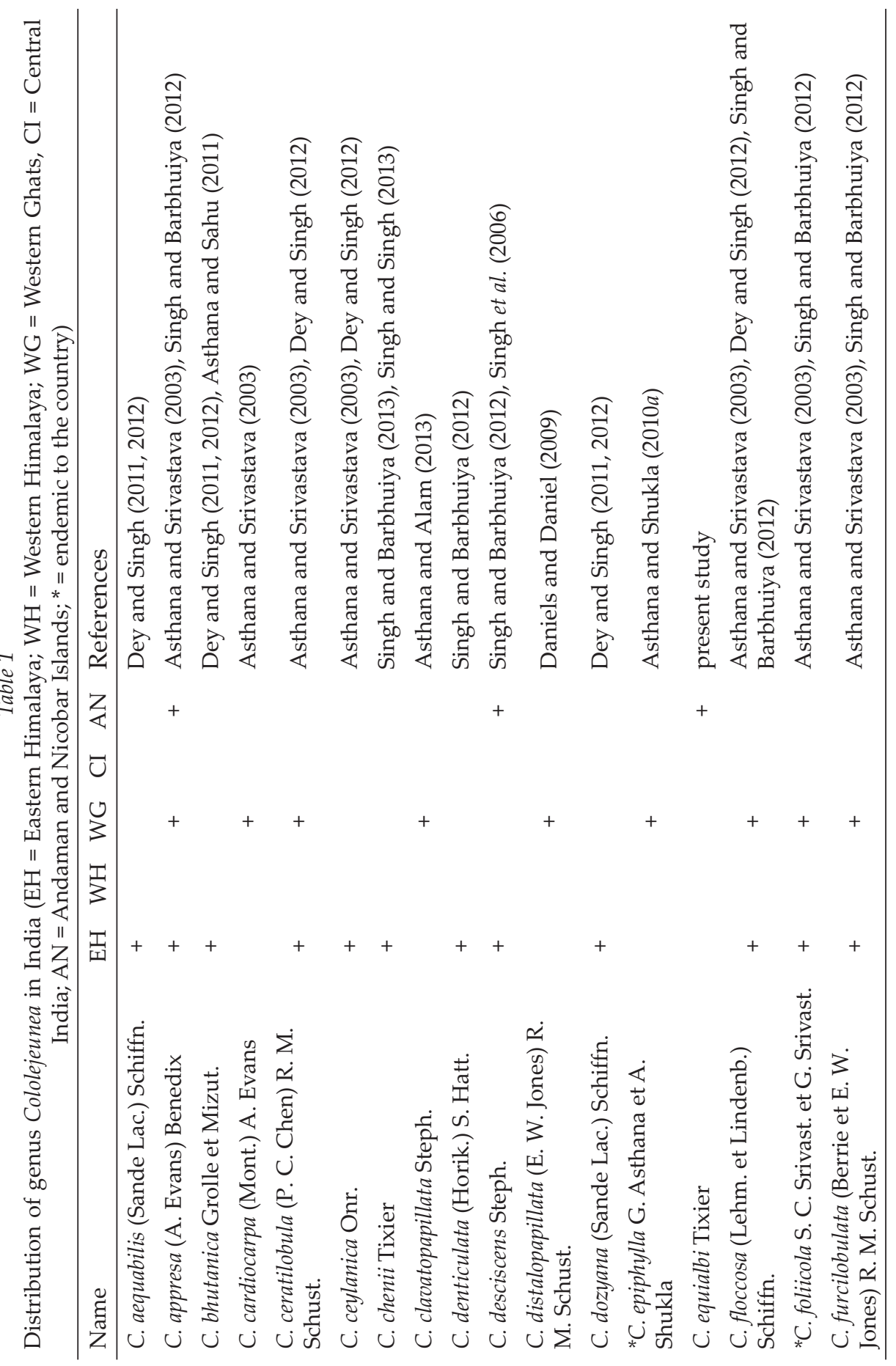




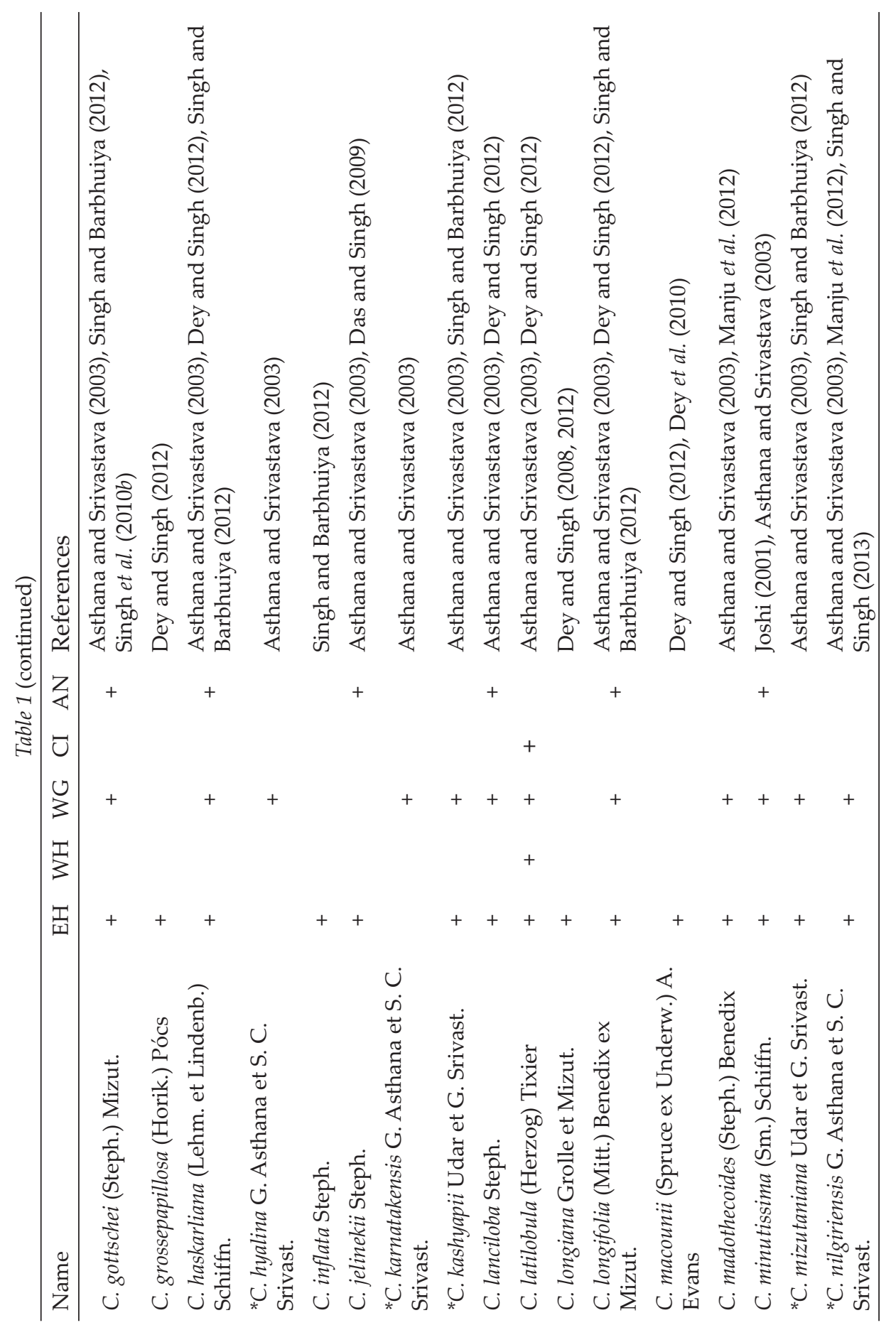




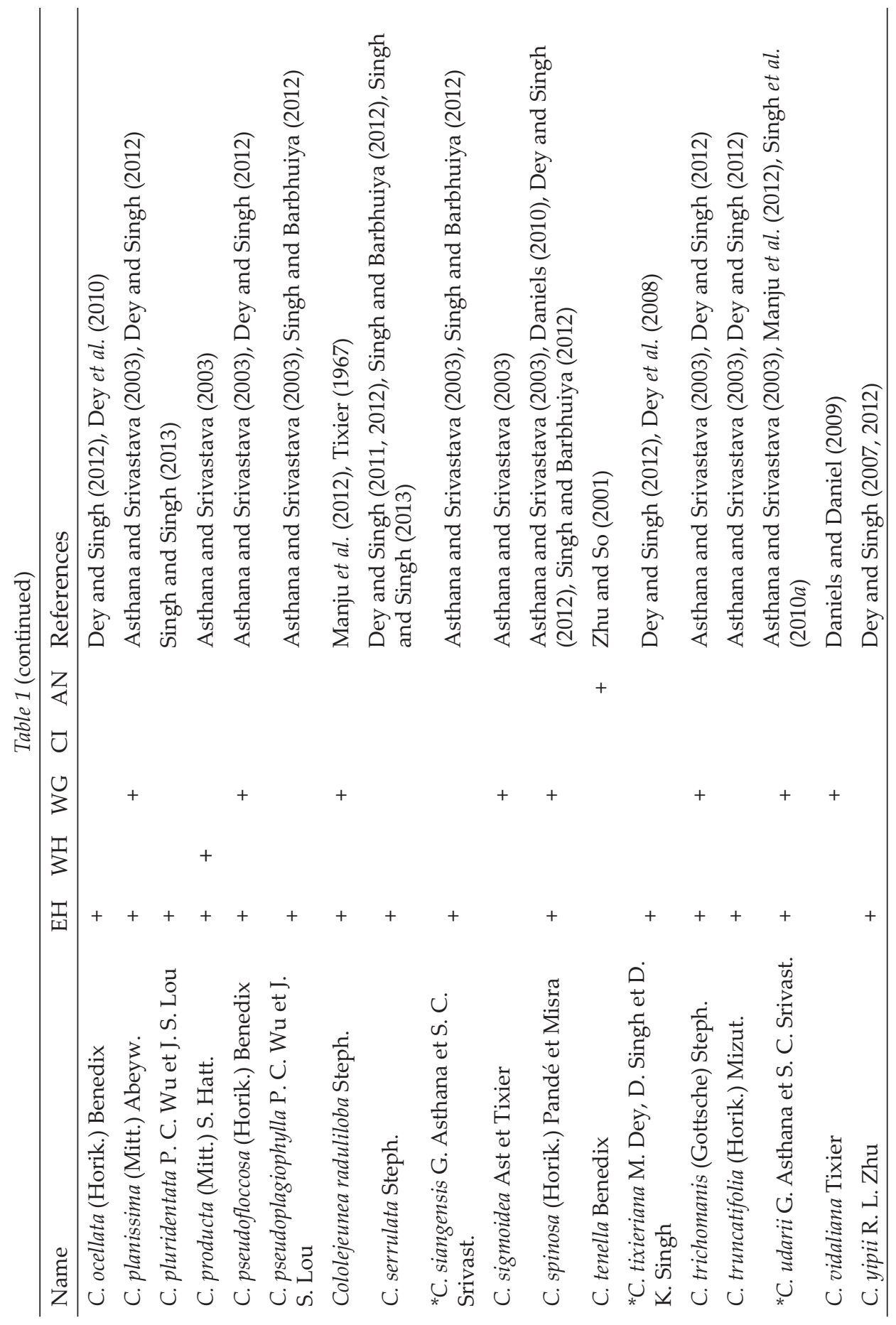


Joshi 2001, Manju et al. 2012, Singh and Barbhuiya 2012, 2013, Singh and Singh 2013, Singh et al. 2006, 2010a, b, Zhu and So 2001). Whereas, the Western Himalayan and the Central Indian bryogeographical regions of the country are represented by just two and a single species of the genus, respectively (Asthana and Srivastava 2003). Ten species of the genus are endemic to the country as indicated by an asterisk $\left(^{*}\right)$ in Table 1 .

Colura pluridentata Ast, Rev. Bryol. Lichénol. 22: 265 (1954)

(Figs 2; 4: 6-10)

Plants light green when fresh, yellowish green in herbarium; shoot 7-11 $\mathrm{mm}$ long, 2.5-4.0 mm wide; branching Lejeunea-type, irregular, sparse. Stem orbicular in outline in transverse section, 110-135 $\mu \mathrm{m}, 4$ cells across the diameter; cortical cells in 7 vertical rows, rectangular to polygonal, 17.5-42.5 $\times$ $30.0-50.0 \mu \mathrm{m}$, thin walled; medullary cells in 3 vertical rows, polygonal, 20 $30 \times 20-35 \mu \mathrm{m}$, thin walled; ventral merophytes of stem 2 cells wide. Leaves closely to loosely imbricate, obliquely spreading, ovate-lanceolate; leaf lobe ovate, 1.1-1.5 mm long, 0.6-1.0 $\mathrm{mm}$ wide, dorsal margin arched, proximal 1/3 entire, distal 2/3 dentate; teeth 1-3(-4) cells long, 1-2(-3) cells wide at base; marginal leaf cells rectangular to polygonal, 15-30 × 20-35 $\mu \mathrm{m}$; median leaf cells hexagonal to polygonal, $37.5-52.5 \times 17.5-27.5 \mu \mathrm{m}$; basal leaf cells polygonal, 45-60 × 22.5-32.5 $\mu \mathrm{m}$; walls thin with large, cordate to nodulose trigones, intermediate thickenings nodulose, 1-2 per wall; surface smooth; oil bodies not seen; leaf lobule inflated, 1.7-2.1 mm long, $0.25-0.32 \mathrm{~mm}$ wide, cylindrical at base, widest at middle, terminating into a strongly inflated, cylindrical to lanceolate sac; sac $0.6-0.7 \mathrm{~mm}$ long, widest at base, narrowing towards rounded to obtuse apex, margin entire; valve ovate, 100-150 × 70-90 $\mu \mathrm{m}$, composed of 34-44 cells, with 2 median basal cells. Underleaves distant, 3-4 times as wide as the stem, $0.4-0.6 \mathrm{~mm}$ long, $0.5-1.0 \mathrm{~mm}$ wide, bilobed to $2 / 3-3 / 4$ of its length, lobes divergent, lanceolate, $8-12$ cells wide at base, $1-2$ cells uniseriate at apex, margin entire, sinus wide. Rhizoids numerous, fasciculate at base of underleaves; rhizoidal disc absent. Gemmae discoid, 22-24-celled, 45.0-82.5 $\mu \mathrm{m}$ in diam., clustered at the apex of leaf lobule. Androecial and gynoecial branches not seen.

Habitat: Epiphyllous, growing on Bulbophyllum Thouars leaves in moist and shady condition, in association with Caudalejeunea recurvistipula, Cheilolejeunea serpentina (Mitt.) Mizut., C. trapezia (Nees) Kachroo et R. M. Schust., Lejeunea tuberculosa Steph., Leptolejeunea epiphylla (Mitt.) Steph., L. maculata (Mitt.) Schiffn., Lopholejeunea subfusca (Nees) Schiffn. and Microlejeunea punctiformis (Taylor) Steph. 


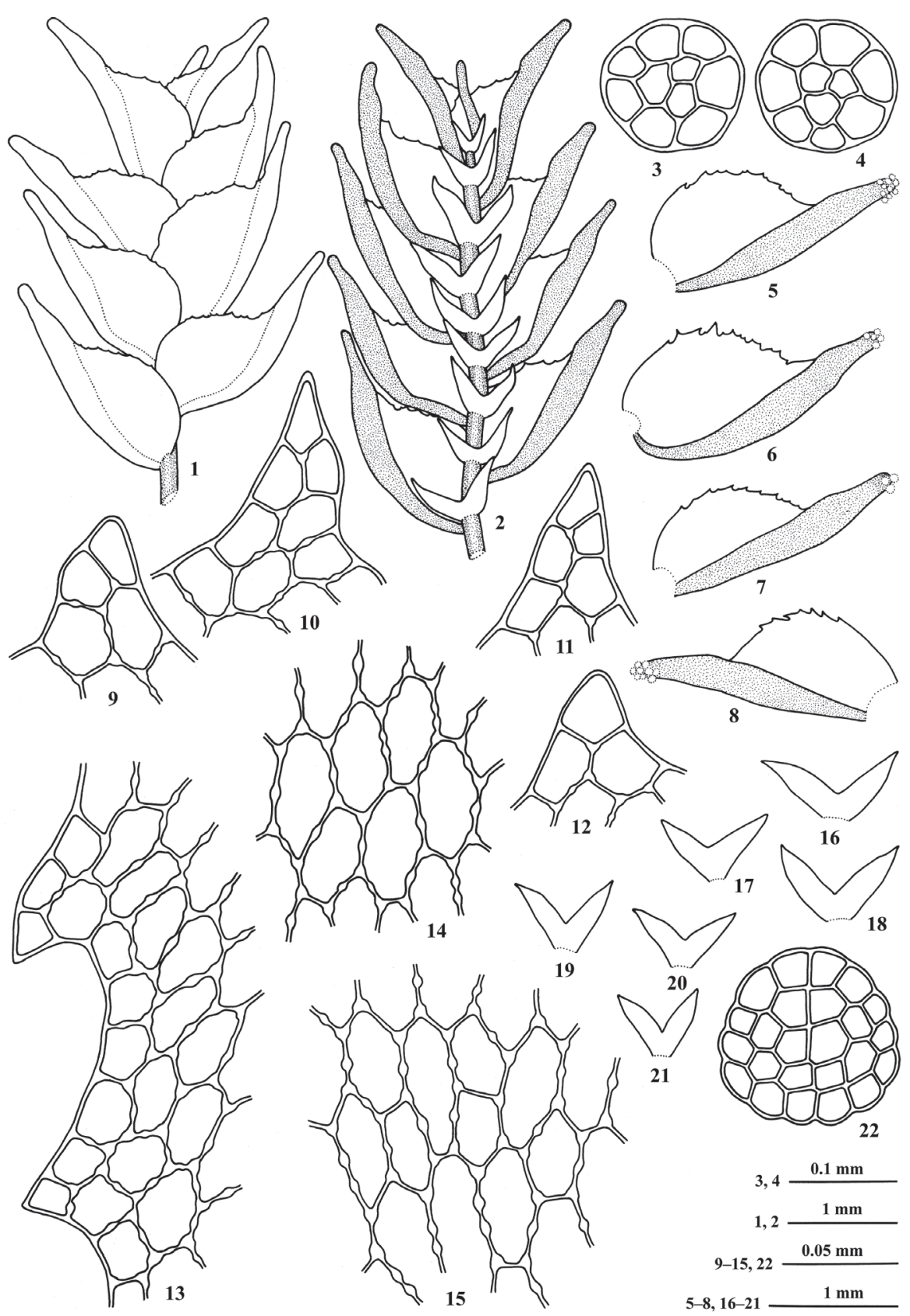

Fig. 2. Colura pluridentata Ast. $1=$ A portion of plant in dorsal view. $2=$ The same in ventral view (rhizoids not drawn). 3-4 = Transverse sections of stem. 5-8 = Leaves. 9-12 = Marginal teeth of leaf lobe. $13=$ Marginal leaf cells. $14=$ Median leaf cells. $15=$ Basal leaf cells. $16-21=$ Underleaves. 22 = A gemma. (All drawn by M. Dey from C. Murugan 61507E) 


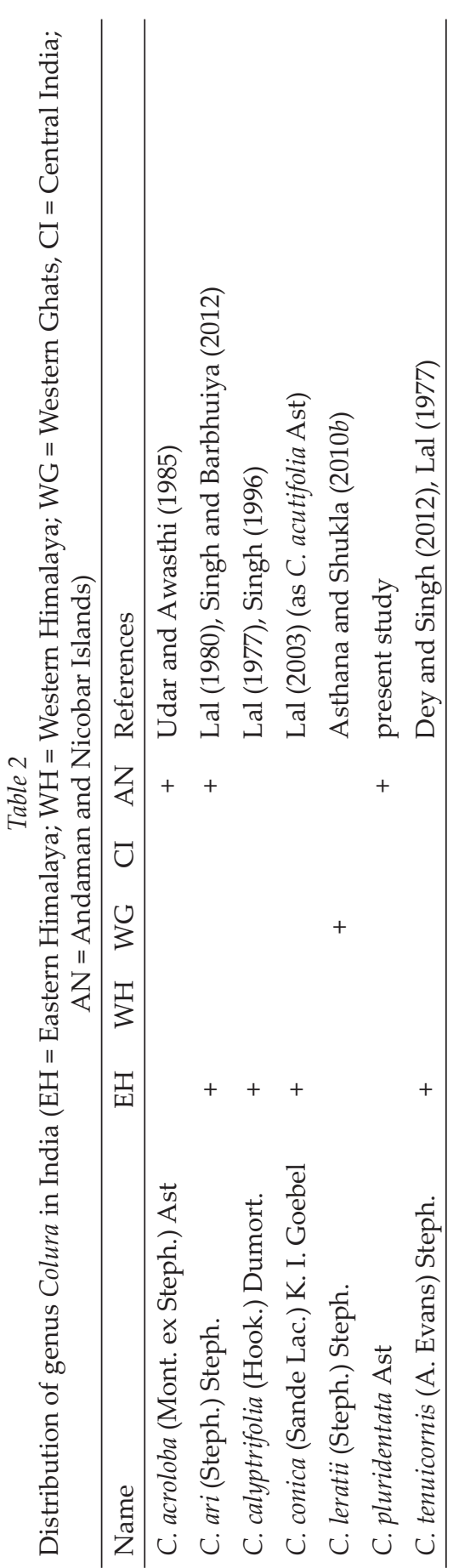

Distribution: India (Andaman and Nicobar Islands (Great Nicobar Island: present study)), Africa (Seychelles), Fiji, Indonesia, Papua New Guinea (JovetAst 1954, Pócs 2013, Pócs and Eggers 2007, Wigginton 2009).

Specimen examined: India, Andaman and Nicobar Islands, Great Nicobar Biosphere Reserve, East-West Road, 12 km from Campbell Bay, ca $176 \mathrm{~m}, 06^{\circ} 59^{\prime} 53^{\prime \prime} \mathrm{N}, 93^{\circ} 52^{\prime} 56^{\prime \prime} \mathrm{E}$, C. Murugan, (61507E) 6 April 2013 (CAL).

Colura pluridentata is characterised by closely to loosely imbricate, obliquely spreading, ovate-lanceolate leaves (Figs 2: 1-2, 5-8; 4: 6); ovate leaf lobes with arched dorsal margin having proximal $1 / 3$ portion entire and distal $2 / 3$ portion dentate; teeth $1-3(-4)$ cells long, 1-2(-3) cells wide at base (Figs 2: 5-13; 4: 7-8); large inflated leaf lobule, which is cylindrical at base, widest at middle, terminating into a strongly inflated, cylindrical to lanceolate sac, which is the widest at base, narrowing towards apex having rounded to obtuse apices and entire margins (Figs 2: 2, 5-8; 4: 6-7); distant underleaves bilobed to $2 / 3-3 / 4$ of their length with divergent, lanceolate lobes, which are 8-12 cells wide at base, 1-2 cells uniseriate at apex (Figs 2: 2, 16-21; 4: 6, 9); and 22-24-celled discoid gemmae clustered at the apex of leaf lobule (Figs 2: 5-8, 22; 4: 6-7, 10).

The Indian plants of $C$. pluridentata fully conform to those from Borneo (Indonesia) described by Jovet-Ast (1954) in all the vital taxonomic parameters except the base of underleaf lobes, which are $8-12$ cells wide in Indian plants, while those from Borneo are up to 8 cells wide. 
The genus Colura (Dumort.) Dumort. has so far been represented in India by six species (Asthana and Shukla 2010b). The Indian species of the genus can be broadly divided into two groups, (i) those with underleaf lobes 2-4 cells wide at base, viz. C. acroloba (Mont. ex Steph.) Ast, C. calyptrifolia (Hook.) Dumort., C. leratii (Steph.) Steph. and C. tenuicornis (A. Evans) Steph. and (ii) those with underleaf lobes 4-6 cells wide at base, viz. C. ari and C. conica (Sande Lac.) K. I. Goebel. Thus C. pluridentata is readily distinguished from hitherto all the known Indian species of the genus in having underleaf lobes 8-12 cells wide at base (Asthana and Shukla 2010b, Dey and Singh 2012, Jovet-Ast 1954, Lal 1980, 2003, Udar and Awasthi 1985). Nevertheless, C. pluridentata shows some resemblance with C. ari, C. conica and C. leratii in having denticulate to dentate leaf lobe margins. But, the similarity ends there, as the three species differ from the former in having obovate leaf lobes with lobule sacs with acute to apiculate apices and denticulate to dentate margins (Asthana and Shukla 2010b, Jovet-Ast 1954, Lal 1980, 2003, Pócs and Eggers 2007).

With the present addition, the number of species of Colura in India has gone up to seven (Table 2). Of these three species are restricted to the Eastern Himalaya in Indian bryoflora, two to Andaman and Nicobar Islands and one to the Western Ghats, while one species is common between the Eastern Himalaya and the Andaman and Nicobar Islands (Asthana and Shukla 2010b, Dey and Singh 2012, Lal 1977, 1980, 2003, Singh 1996, Singh and Barbhuiya 2012, Udar and Awasthi 1985).

\section{Drepanolejeunea thwaitesiana var. thwaitesiana (Mitt.) Steph., Sp. Hepat. 5: 350 (1913) $\equiv$ Lejeunea thwaitesiana Mitt., J. Proc. Linn. Soc., Bot. 5: 117 (1861)}

(Figs 3; 4: 11-15)

Plants light green when fresh, yellowish-brownish green in herbarium; shoot 5-13 mm long, 0.8-1.2 mm wide; branching Lejeunea-type, irregular. Stem orbicular to sub-orbicular in outline in transverse section, 50.0-62.5 $\mu \mathrm{m}, 4$ cells across the diameter; cortical cells in 7 vertical rows, rectangular to polygonal, $10.0-20.0 \times 12.5-27.5 \mu \mathrm{m}$, slightly thick walled; medullary cells in 3 vertical rows, rectangular to polygonal, 10.0-12.5 $\times 10.0-12.5 \mu \mathrm{m}$, slightly thick walled; ventral merophytes of stem 2 cells wide. Leaves imbricate, obliquely spreading; leaf lobe ovate, slightly falcate, $0.49-0.62 \mathrm{~mm}$ long, 0.34-0.42 mm wide, apex acute to apiculate, margin irregularly dentate, dorsal margin arched, narrowing towards base, ventral margin nearly straight; apical leaf cells rectangular to polygonal, 10-15 × 10.0-17.5 $\mu \mathrm{m}$; median leaf cells polygonal, $20.0-27.5 \times 17.5-22.5 \mu \mathrm{m}$; basal leaf cells polygonal, $25.0-52.5$ $\times 10.0-20.0 \mu \mathrm{m}$; walls thin to slightly thick with small to medium trigones, in- 
termediate thickenings small; surface smooth; oil bodies not seen; ocelli 6-12 per leaf lobe, irregularly scattered, suprabasal ocelli 1-2, 35.0-47.5 × 15-20 $\mu \mathrm{m}$; median ocelli 5-11, 27.5-32.5 × 15-20 $\mu \mathrm{m}$; leaf lobule inflated, 1/3-2/5 as long as the lobe, oblong to ovate, $0.16-0.22 \mathrm{~mm}$ long, $0.09-0.12 \mathrm{~mm}$ wide, bidentate, first tooth unicellular, oblong, straight; second tooth obsolete; hyaline papilla at the proximal side of first tooth; free lateral margin bordered by 6-7 subquadrate to rectangular cells; keel straight to slightly arched, smooth. Underleaves distant, 4-6 times as wide as stem, 0.06-0.11 mm long, 0.17-0.34 $\mathrm{mm}$ wide, bilobed to $3 / 4$ of its length; lobes lanceolate, 5-8 cells long, 2 cells wide at base, $2-4$ cells uniseriate at apex, very widely spreading to nearly horizontal. Rhizoids numerous, fasciculate at the base of underleaves. Asexual reproduction by means of brood branches, $0.8-1.4 \mathrm{~mm}$ long, $0.6-0.9 \mathrm{~mm}$ wide; the lobule of the first leaf reduced; the first underleaf with an adhesive disc or paramphigastrium.

Dioicous. Androecia terminal on main shoot or lateral branches; bracts in 4-8 pairs, densely imbricate; bract lobe ovate, $0.15-0.24 \mathrm{~mm}$ long, $0.12-0.16$ mm wide, apex acute, margin dentate; bract lobule strongly inflated, almost as long as the bract lobe; bracteole 1 , present only at the base of androecium, $0.11-0.13 \mathrm{~mm}$ long, $0.10-0.16 \mathrm{~mm}$ wide, bilobed to $2 / 3$ of its length; lobes linear to lanceolate, 4-5 cells long, 2 cells wide at base, 2-3 cells uniseriate at apex. Gynoecial branches not seen.

Habitat: Epiphyllous, growing on Calamus andamanicus Kurz, Garcinia nervosa and Teijsmanniodendron pteropodum (Miq.) Bakh. leaves in moist and shady condition, in association with Caudalejeunea recurvistipula, Cololejeunea equialbi, C. floccosa, Colura ari, Drepanolejeunea pentadactyla (Mont.) Steph., Lejeunea anisophylla, Leptolejeunea maculata, Lopholejeunea sikkimensis Steph. var. sikkimensis, Radula acuminata Steph., Radula tjibodensis.

Distribution: India (Andaman and Nicobar Islands (Great Nicobar Island: present study)), Cambodia, China, Indonesia, Malaysia, New Guinea, Sri Lanka, Thailand, Vietnam (Mizutani 1990, Onraedt 1981, Zhu and So 2001).

Specimens examined: India, Andaman and Nicobar Islands: Great Nicobar Biosphere Reserve, East-West Road, 15.5 km from Campbell Bay, ca 80 m, 06 59' 15" N, 93 51' 92" E, C. Murugan. (61511A), 6 April 2013 (CAL); Great Nicobar Biosphere Reserve, Campbell Bay, 07 0.219’ N, 93 52.794' E, D. K. Singh. (61642B, 61644F, 61645B), 7 February 2014 (CAL); Great Nicobar Biosphere Reserve, Campbell Bay, ca 56 m, 07 0.282’ N, $93^{\circ} 52.765^{\prime}$ E, D. K. Singh. (61650E, 61652F), 7 February 2014 (CAL).

Other specimens examined: Hepaticae Selectae et Criticae (ed. Fr. Verdoorn), ser. XI, 1939, Indonesia. Java Occid.: Priangan, ca 2,200 m, Fr. Verdoorn. (505), July 1930 (CAL); Java Centr.: Banjoemas, ca 1,700 m, Fr. Verdoorn. (506), June 1930 (CAL).

Drepanolejeunea thwaitesiana var. thwaitesiana is characterised by ovate, slightly falcate leaf lobes with acute to apiculate apices and irregularly dentate 


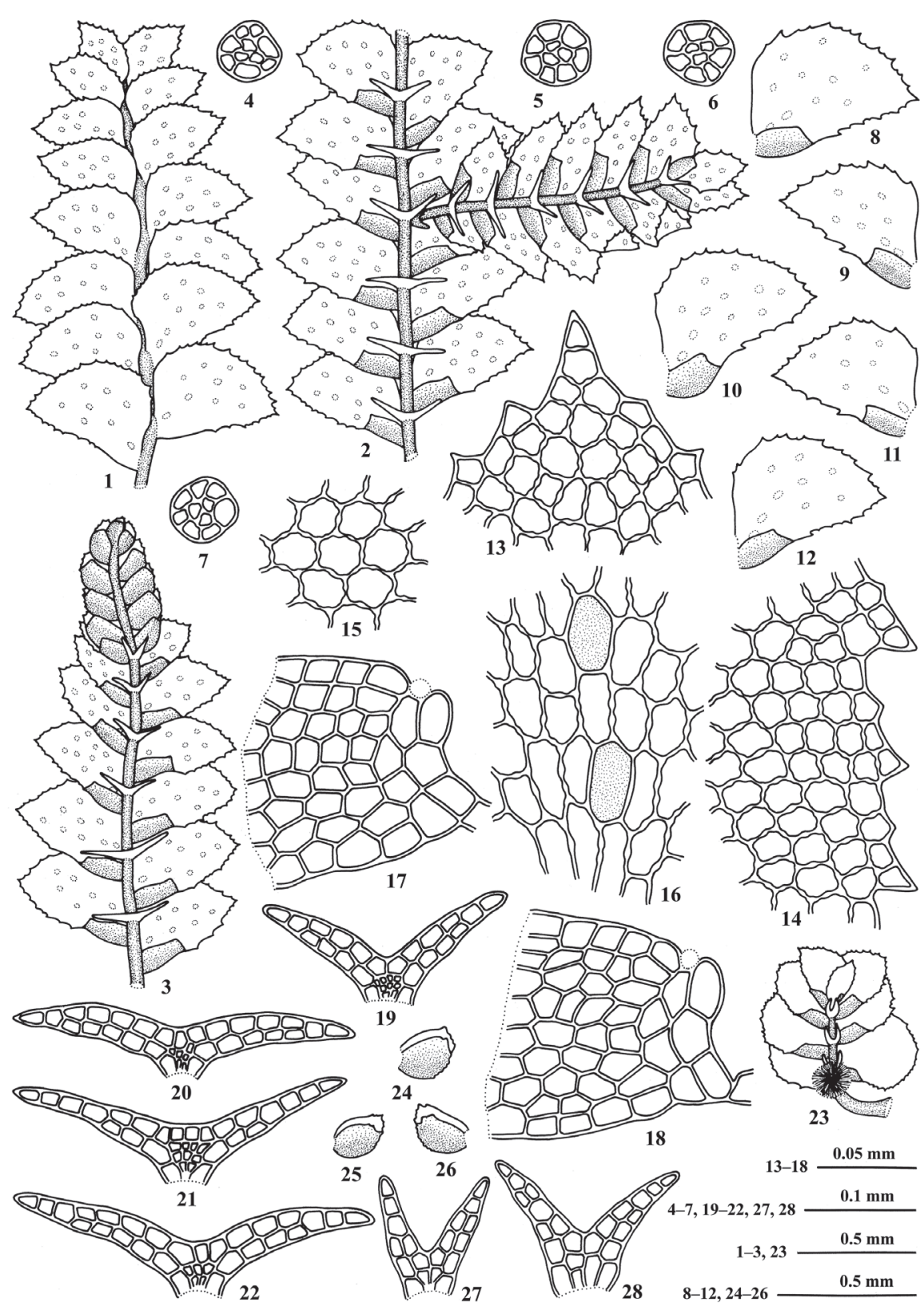

Fig. 3. Drepanolejeunea thwaitesiana (Mitt.) Steph. var. thwaitesiana. $1=$ A portion of plant in dorsal view. 2 = The same in ventral view (rhizoids not drawn). $3=\mathrm{A}$ portion of male plant in ventral view. $4-7=$ Transverse sections of stem. $8-12=$ Leaves. $13=$ Apical leaf cells. $14=$ Marginal leaf cells. $15=$ Median leaf cells. $16=$ Basal leaf cells showing ocelli. $17-18=$ Apices of leaf lobules. 19-22 = Underleaves. 23 = A brood branch in ventral view. 24-26= Male bracts. 27-28 = Male bracteoles. (All drawn by M. Dey from C. Murugan 61511A) 


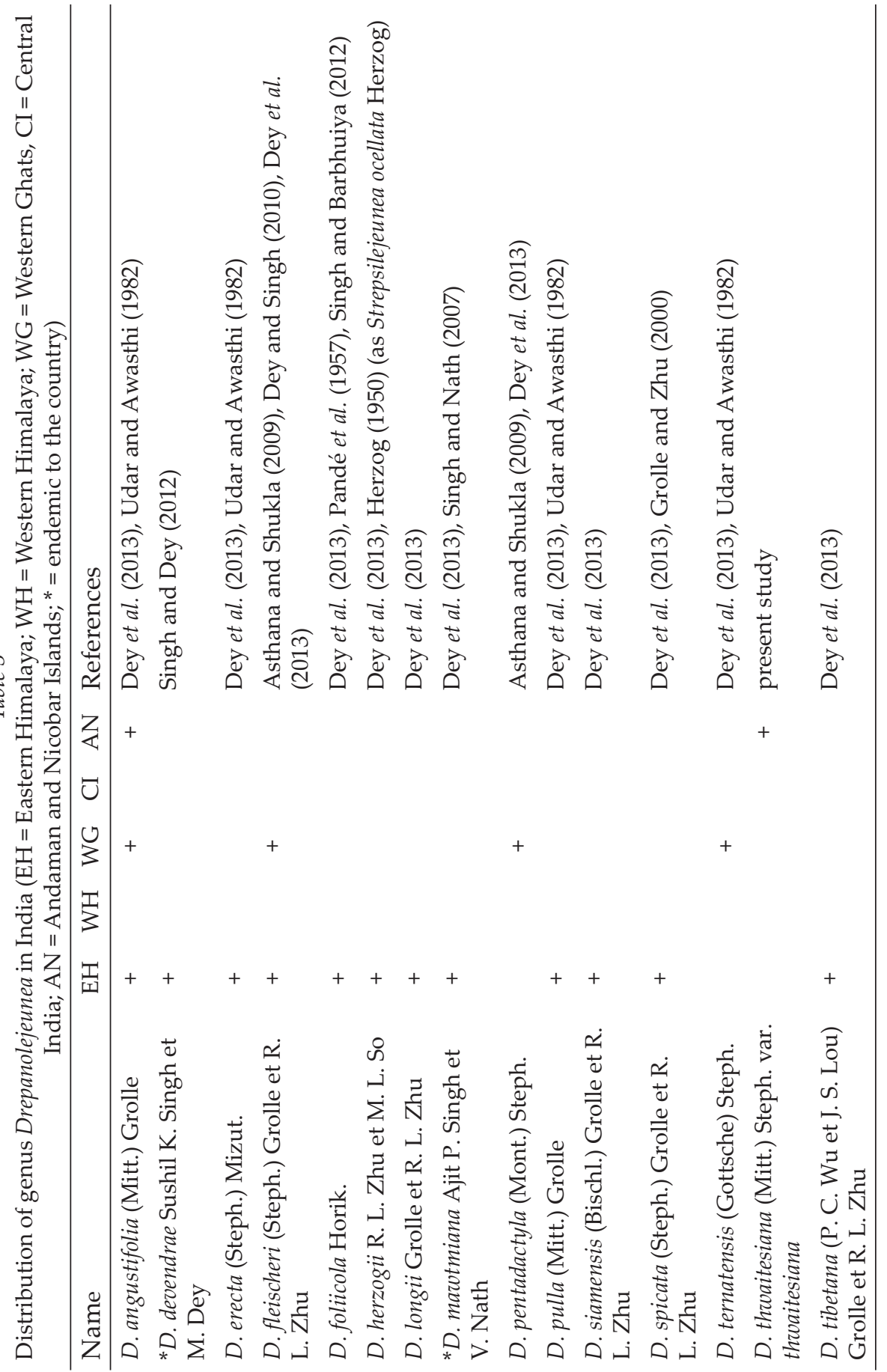


margin (Figs 3: 1-3, 8-14; 4: 11-14); irregularly scattered 6-12 ocelli per leaf lobe (Fig. 3: 1-3, 8-12); oblong to ovate, inflated leaf lobule, $1 / 3-2 / 5$ as long as the leaf lobe with unicellular, oblong, straight first tooth and the free lateral margin bordered by $6-7$ subquadrate to rectangular cells (Figs 3: 2-3, 8-12, 17-18; 4: 11-12, 15); underleaves divided to $3 / 4$ of its length with very widely spreading to nearly horizontal lanceolate lobes 5-8 cells long, 2 cells wide at base, $2-4$ cells uniseriate at apex (Figs 3: 2-3, 19-22; 4: 15); terminal androecia with 4-8 pairs of densely imbricate bracts and a single bracteole present only at the base of androecium (Figs 3: 3; 4: 11).

Drepanolejeunea thwaitesiana var. thwaitesiana shows considerable variation in the size of plants and leaves and the number of ocelli per leaf and male bracteole per androecial branch. Stephani (1913) described larger, up to $2 \mathrm{~cm}$ long plants with larger, $1.5 \times 0.67 \mathrm{~mm}$ leaves, each having 4-5 ocelli only in plants from Java, Mauritius, New Guinea and Sri Lanka. Mizutani (1990) reported 10-15 mm long plants with $0.55-0.75 \times 0.32-0.5$ mm leaves bearing 10-30 ocelli per lobe, while Zhu and So (2001) observed 5-12 mm long plants with 0.54-0.72 $\times 0.35-0.45 \mathrm{~mm}$ leaves bearing 6-25 ocelli per lobe and with or without a single male bracteole in Chinese plants of the species. Similarly, the specimens from Java (Fr. Verdoorn 505, 506 (CAL)) show 8-15 mm long plants with $0.55-0.85 \times 0.35-0.48 \mathrm{~mm}$ leaves bearing $8-14$ ocelli per lobe and 1-2 male bracteoles present at the base of androecium. The Indian plants of $D$. thwaitesiana var. thwaitesiana, therefore, compare well with those from China, fall within the overall range of variation of the species across its range of distribution.

The genus Drepanolejeunea (Spruce) Schiffn. has so far been represented in India by 16 species (Dey and Singh 2012, Dey et al. 2013, He and Zhu 2014, Singh and Dey 2012). All the Indian species of Drepanolejeunea known so far have only 1-2 ocelli per leaf lobe, except $D$. pentadactyla, which has $2-4$ ocelli per leaf lobe (Asthana and Shukla 2009, Dey and Singh 2012, Dey et al. 2013, Grolle and Zhu 1999, 2000, Singh and Dey 2012, Singh and Nath 2007, Udar and Awasthi 1982, 1984, Zhu 


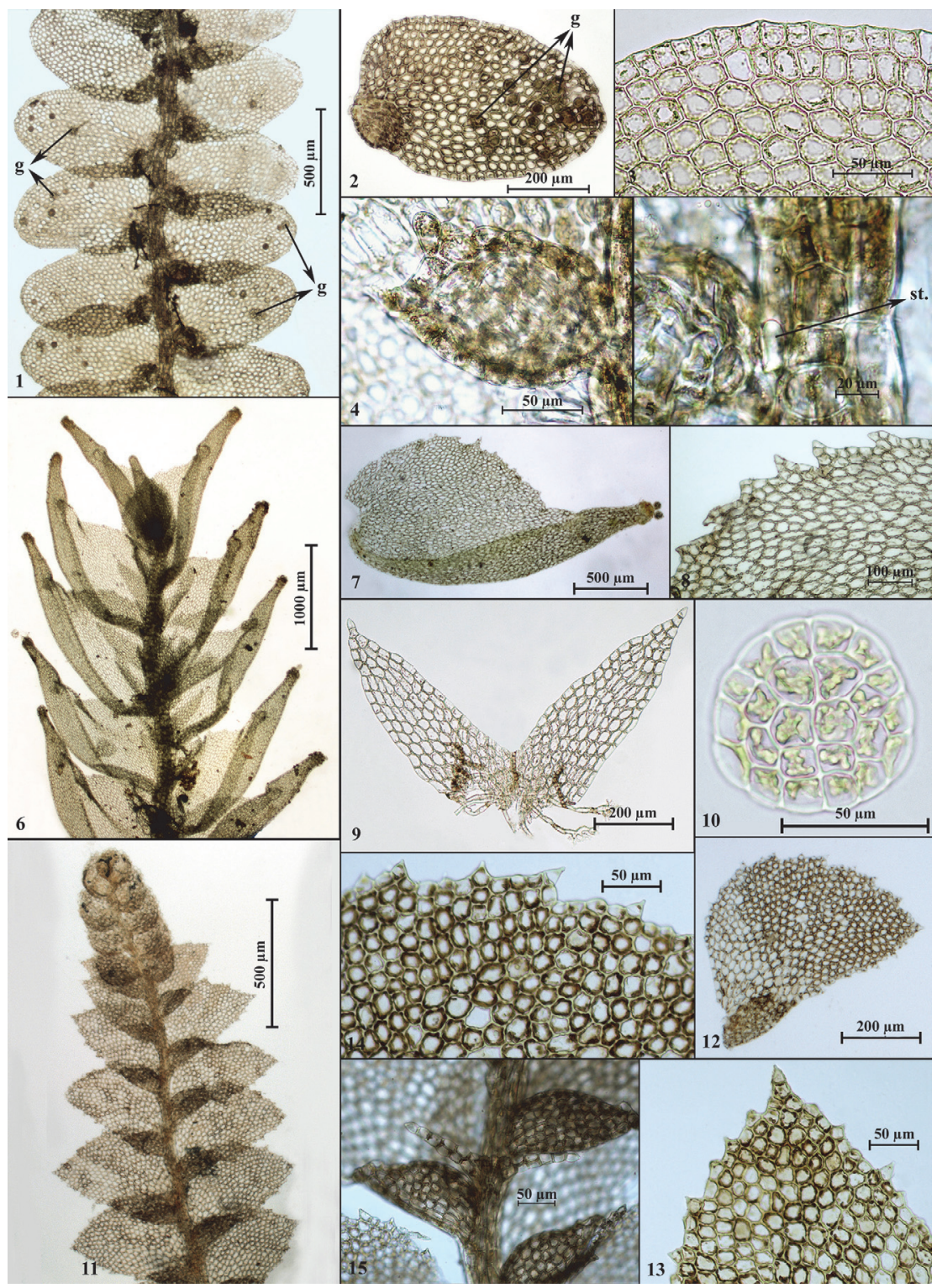

Fig. 4. Cololejeunea equialbi Tixier. 1 = A portion of plant in ventral view. $2=\mathrm{A}$ leaf bearing gemmae ( $\mathrm{g}=$ gemmae). 3 = Marginal leaf cells. $4=$ A leaf lobule. $5=$ Base of leaf lobule and portion of stem showing a stylus (st. = stylus). - Colura pluridentata Ast. $6=$ A portion of plant in ventral view. $7=$ A leaf. $8=$ Marginal leaf cells. $9=$ An underleaf. $10=$ A gemma. - Drepanolejeunea thwaitesiana (Mitt.) Steph. var. thwaitesiana. 11 = A portion of male plant in ventral view. $12=$ A leaf. $13=$ Apical leaf cells. $14=$ Marginal leaf cells. $15=$ A portion of stem showing underleaf. (All photographs by M. Dey, 1-5 from C. Murugan 61505C, 6-10 from C. Murugan 61507E, 11-15 from C. Murugan 61511A) 
and So 2001). In the presence of 6-12 irregularly scattered ocelli per leaf lobe, therefore, $D$. thwaitesiana var. thwaitesiana is considerably distinct from all the hitherto known Indian species of the genus. Yet, D. thwaitesiana var. thwaitesiana partially resembles $D$. longii Grolle et $R$. L. Zhu in general appearance and the presence of ovate, slightly falcate leaf lobes with acute apices and irregularly dentate margin. However, $D$. longii can be easily distinguished from the present species in having strongly curved first tooth of leaf lobule and male bracteoles present throughout the androecium (Dey and Singh 2012, Dey et al. 2013, Grolle and Zhu 1999).

The present addition raises the number of taxa of Drepanolejeunea known in the Indian bryoflora to seventeen (Table 3). The Eastern Himalaya, including the northeastern states, with 14 species recorded from the region show the maximum diversity of the genus in India. Of these 11 species are restricted to this bryogeographical region alone in the Indian bryoflora. This is followed by the Western Ghats with five species, two of which are confined to this region and the Andaman and Nicobar Islands with two species. D. fleischeri (Steph.) Grolle et R. L. Zhu and D. yunnanensis (P. C. Chen) Grolle et R. L. Zhu are common between the Eastern Himalaya and the Western Ghats, while $D$. angustifolia (Mitt.) Grolle is known from all the three regions (Dey et al. 2013, Singh and Barbhuiya 2012, Singh and Dey 2012). Two of these species, viz. D. devendrae Sushil K. Singh et M. Dey and D. mawtmiana Ajit P. Singh et V. Nath are endemic to the country as indicated by an asterisk $\left(^{*}\right)$ in Table 3.

Acknowledgements - The authors thank the Director, Botanical Survey of India for facilities and encouragement. One of us (MD) is also grateful to the Director, BSI for financial assistance under the A. J. C. Bose Post Doctoral Fellowship programme of the department.

\section{REFERENCES}

Asthana, A. K. and Sahu, V. (2011): Cololejeunea bhutanica Grolle \& Mizut., a new record for India. - Geophytology 40: 115-118.

Asthana, G. and Alam, A. (2013): Cololejeunea clavatopapillata Steph. new to Asia. - Bryoph. Div. Evol. 35: 39-42. http://dx.doi.org/10.11646/bde.35.1.4

Asthana, G. and Shukla, A. (2009): Two epiphyllous species of Drepanolejeunea (Spruce) Schiffn. new to the Indian bryoflora. - J. Bryol. 31: 139-142.

Asthana, G. and Shukla, A. (2010a): A new epiphyllous species of Cololejeunea (Lejeuneaceae) from India. - Cryptog. Bryol. 31: 217-221.

Asthana, G. and Shukla, A. (2010b): Colura leratii (Steph.) Steph. new to India. - Bryoph. Div. Evol. 32: 100-102. http://dx.doi.org/10.11646/bde.32.1.13

Asthana, G. and Srivastava, S. C. (2003): Indian Cololejeunea. A taxonomic study. - Bryophyt. Biblioth. 60: 1-155. 
Daniels, A. E. D. (2010): Checklist of the bryophytes of Tamil Nadu, India. - Arch. Bryol. 65: $1-117$.

Daniels, A. E. D. and Daniel, P. (2009): Cololejeunea distalopapillata and C. vidaliana (Lejeuneaceae) new to the liverwort flora of India. - Acta Bot. Hung. 51: 61-66. http:// dx.doi.org/10.1556/ABot.51.2009.1-2.8

Das, S. and Singh, D. K. (2009): Three new records of liverworts for Himalayan region from Mehao Wildlife Sanctuary, Arunachal Pradesh. - Nelumbo 51: 191-198.

Dey, M. and Singh, D. K. (2007): Cololejeunea yipii R. L. Zhu (Hepaticae: Lejeuneaceae), new to Indian bryoflora from West Siang, Arunachal Pradesh. - Phytotaxonomy 7: 35-37.

Dey, M. and Singh, D. K. (2008): Cololejeunea longiana Grolle \& Mizut., an addition to Indian bryoflora from Darjeeling, West Bengal. - Bull. Bot. Surv. India 50: 209-211.

Dey, M. and Singh, D. K. (2010): Drepanolejeunea fleischeri (Steph.) Grolle \& R. L. Zhu (Hepaticae: Lejeuneaceae): an addition to Indian Himalaya. - Geophytology 39: 65-71.

Dey, M. and Singh, D. K. (2011): Four foliicolous species of Cololejeunea (Spruce) Schiffn. (Marchantiophyta: Lejeuneaceae) new to India. - J. Bryol. 33(2): 162-166. http:// dx.doi.org/10.1179/1743282010y.0000000022

Dey, M. and Singh, D. K. (2012): Epiphyllous liverworts of Eastern Himalaya. - Botanical Survey of India, Thiruvananthapuram, $415 \mathrm{pp}$.

Dey, M., Singh, D. and Singh, D. K. (2008): A new species of Cololejeunea (Hepaticae: Lejeuneaceae) from Eastern Himalaya, India. - Taiwania 53: 258-263.

Dey, M., Singh, D. and Singh, D. K. (2010): Two more additions to Indian Cololejeunea (Hepaticae: Lejeuneaceae) from West Sikkim. - Indian J. Forest. 33: 615-618.

Dey, M., Singh, D. and Singh, D. K. (2013): The genus Drepanolejeunea (Marchantiophyta: Lejeuneaceae) in India with a note on three new additions from Eastern Himalaya. Bryoph. Div. Evol. 35: 14-25. http://dx.doi.org/10.11646/bde.35.1.2

Ellis, L. T., Bednarek-Ochyra, H., Ochyra, R., Benjumea, M. J., Saïs, L. V., Caparrós, R., Lara, F., Mazimpaka, V., Dulin, M. V., Garilleti, R., Gremmen, N., Grundling, P.-L., Heras, P., Infante, M., Huttunen, S., Ignatov, M. S., Korvenpää, T., Lebouvier, M., Lewis Smith, R. I., Lin, S.-H., Yang, J.-D., Linström, A., Plášek, V., Rosselló, J. A., Sawicki, J., van Rooy, J. and Smith, V. R. (2013): New national and regional bryophyte records, 35. - J. Bryol. 35(2): 129-139. http://dx.doi.org/10.1179/1743282013y.0000000049

Gradstein, S. R. (2013): A classification of Lejeuneaceae (Marchantiophyta) based on molecular and morphological evidence. - Phytotaxa 100: 6-20. http://dx.doi.org/10.11646/ phytotaxa.100.1.2

Grolle, R. and Zhu, R.-L. (1999): Drepanolejeunea longii (Lejeuneaceae, Hepaticae), a new species from Bhutan. - Ann. Bot. Fenn. 36: 115-118.

Grolle, R. and Zhu, R.-L. (2000): A study of Drepanolejeunea subg. Rhaphidolejeunea (Herzog) Grolle \& R. L. Zhu, stat. nov. (Hepaticae, Lejeuneaceae) in China with notes on its species elsewhere. - Nova Hedwigia 70: 373-395.

He, Q. and Zhu, R.-L. (2014): Notes on Early Land Plants Today. 48. Drepanolejeunea longifolia, a new synonym of Drepanolejeunea angustifolia (Marchantiophyta, Lejeuneaceae). - Phytotaxa 162: 234-235. http://dx.doi.org/10.11646/phytotaxa.162.4.7 Herzog, T. (1950): Miscellanea bryologica II. Palaeotropica. - Mem. Soc. Fauna Flora Fenn. 26: $37-66$.

Joshi, D. Y. (2001): A floristic analysis of the liverworts from Andaman Islands, India. - In: Nath, V. and Asthana, A. K. (eds): Perspectives in Indian Bryology. Bishen Singh Mahendra Pal Singh, Dehra Dun, pp. 135-148. 
Jovet-Ast, S. (1954): Le genre Colura, Hépatiques. Lejeuneaceae, Diplasiae. - Rev. Bryol. Lichénol. 22: 206-312.

Lal, J. (1977): Colura Dum. (Hepaticae), a genus new to Indian Flora. - Curr. Sci. 46: 618.

Lal, J. (1980): Colura ari Steph. (Hepaticae) from Andamans, a new record for India. - Bull. Bot. Surv. India 22: 207-209.

Lal, J. (2003): Colura acutifolia Ast (Hepaticae), new to Indian bryoflora. - Bull. Bot. Surv. India 45: 227-228.

Manju, C. N., Pócs, T., Rajesh, K. P. and Prakashkumar, R. (2012): Lejeuneaceae (Marchantiophyta) of the Western Ghats, India. - Acta Biol. Plant. Agriensis 2: 127-147.

Mizutani, M. (1975): Epiphyllous species of Lejeuneaceae from the Philippines. - J. Hattori Bot. Lab. 39: 255-262.

Mizutani, M. (1978): Lejeuneaceae from Ishigaki and Iriomote Islands of Ryukyu Archipelago. - J. Hattori Bot. Lab. 44: 121-136.

Mizutani, M. (1986): Lejeuneaceae from Seram Island, Indonesia. - J. Hattori Bot. Lab. 61: 299-308.

Mizutani, M. (1990): Notes on the Lejeuneaceae. 16. Drepanolejeunea thwaitesiana and its related species from Asia. - J. Hattori Bot. Lab. 68: 367-380.

Onraedt, M. (1981): Bryophytes récoltées a Sri Lanka (Ceylan) V. - J. Hattori Bot. Lab. 50: 191-216.

Pandé, S. K., Srivastava, K. P. and Ahmad, S. (1957): Epiphyllous liverworts of India and Ceylon II. - J. Indian Bot. Soc. 36: 335-347.

Pócs, T. (2013): The genus Colura (Lejeuneaceae) in New Guinea and in the neighboring areas. - Chenia 11: 12-38.

Pócs, T. and Eggers, J. (2007): Bryophytes from the Fiji Islands, II. An account of the genus Colura, with a description of C. vitiensis sp. nov. - Polish Bot. J. 52: 81-92.

Pócs, T., Mizutani, M. and Piippo, S. (1994): Bryophyte flora of the Huon Peninsula, Papua New Guinea. LXV. Preliminary contributions on Lejeuneaceae (Hepaticae) 1. - Ann. Bot. Fenn. 31: 179-190.

Pócs, T., Sass-Gyarmati, A., Naikatini, A., Tiuwawa, M., Braggins, J., Pócs, S. and von Konrat, M. (2011): New liverwort (Marchantiophyta) records for the Fiji Islands. - Telopea 13: 455-494.

Singh, A. P. and Nath, V. (2007): Hepaticae of Khasi and Jaintia Hills: Eastern Himalayas. Bishen Singh Mahendra Pal Singh, Dehra Dun, 382 pp.

Singh, D. and Singh, D. K. (2013): Some new and noteworthy records of family Lejeuneaceae (Marchantiophyta) from Sikkim, India. - Nelumbo 55: 153-165.

Singh, D., Dey, M. and Singh, D. K. (2010a): A synoptic flora of liverworts and hornworts of Manipur. - Nelumbo 52: 9-52.

Singh, D., Dey, M. and Upadhyay, G. K. (2010b): A preliminary survey of Hepaticae of Little Andaman Island. - Nelumbo 52: 125-130.

Singh, D. K. (1996): Hepaticae (Bryophyta). - In: Hajra, P. K (ed.): A contribution to the flora of Namdapha Arunachal Pradesh. Botanical Survey of India, New Delhi, pp. 46-67.

Singh, D. K., Singh, S. K. and Dey, M. (2006): On a collection of Hepaticae from Andaman Islands. - Phytotaxonomy 6: 99-104.

Singh, S. K. and Barbhuiya, H. A. (2012): A compendium to Marchantiophyta and Anthocerotophyta of Assam, India. - Arch. Bryol.149: 1-30.

Singh, S. K. and Barbhuiya, H. A. (2013): Contributions to the Hepaticae and Anthocerotae of Mizoram VI. Cololejeunea chenii new to India. - Acta Bot. Hung. 55: 135-139. http://dx.doi.org/10.1556/ABot.55.2013.1-2.9 
Singh, S. K. and Dey, M. (2012): A new species of Drepanolejeunea (Marchantiophyta: Lejeuneaceae) from India. - Nelumbo 54: 20-23.

Stephani, F. (1912-1917): Species Hepaticarum 5. - Georg \& Cie, Lyon, mème Maison, Genève et Bale, 1044 pp.

Tixier, P. (1967): Bryophytae Indosinicae. - Dacca Univ. Stu. 15: 1-14.

Tixier, P. (1970): Contribution a la connaissance du genre Cololejeunea en Asie du Sud-Est II. la section Radulae (nov-sect.) du sous-genre Lasiolejeunea. - Ann. Fac. Sci. Phnom Penh 3: 177-190.

Udar, R. and Awasthi, U. S. (1982): The genus Drepanolejeunea St. in India. - J. Hattori Bot. Lab. 53: 419-437.

Udar, R. and Awasthi, U. S. (1984): The genus Rhaphidolejeunea Hork. in India. - Yushania 1: 15-18.

Udar, R. and Awasthi, U. S. (1985): Colura acroloba (Mont.) Jovet-Ast, new to Indian bryoflora. - J. Indian Bot. Soc. 64: 284-286.

Wigginton, M. J. (2009): Checklist and distribution of the liverworts and hornworts of subSaharan Africa, including the East African Islands. - Trop. Bryol. Res. Rep. 8: 1-116.

Zhu, R.-L. and So, M.-L. (2001): Epiphyllous liverworts of China. - Beih. Nova Hedwigia 121: 1-418. 